\title{
Angiographical study of ramus intermedius coronary artery in Basrah
}

\author{
Saja M. Ali ${ }^{1}$
}

\section{ABSTRACT}

Background: Ramus intermedius artery is one of the branches of epicardial coronary artery. It shares in supplying the lateral wall of left ventricle. It is regarded as normal anatomical variant that creates appearance of trifurcation of left coronary artery. The atherosclerotic changes in this artery lead to peculiar clinical signs even when other main coronary arteries are preserved and at this time it requires either percutanous coronary intervention or cardiac bypass surgery.

Objectives: To know the incidence of ramus intermedius artery among people in Basrah and the significance of its occurrence in interpretation of coronary angiography and surgical revascularization of myocardium.

Patients and Methods: This is a prospective study of coronary angiography carried out in Basra cardiac center at Al-Sadder Teaching Hospital. A sample of $\mathbf{1 1 0}$ patients with normal coronary arteries were also recruited.

Results: In the present study the sample size was 110 cases; male patients were $61.8 \%$ and the female patients were $38.2 \%$; the age of patients were ranged from 35 to 79 years ( $52 \pm 4.1$ years). The ramus intermedius artery was present in $\mathbf{3 0 \%}$ of cases; the incidence of ramus intermedius artery in male was $33.8 \%$, female $23.8 \%$ while the incidence of this artery in people who live in urban area was $35.7 \%$, rural area $\mathbf{2 4 . 1 \%}$. The length of ramus intermedius artery was variable (mean $59.40 \pm 5.48 \mathrm{~mm}$ ); in male $53.6 \pm$ $2.6 \mathrm{~mm}$, female $61.8 \pm 3.15 \mathrm{~mm}$ and the caliber of this artery (mean $2.13 \pm 2.41 \mathrm{~mm}$ ) in male was $1.52 \pm$ $1.01 \mathrm{~mm}$, female $2.39 \pm 0.24 \mathrm{~mm}$.

Conclusions: The ramus intermedius artery would be of great significance in coronary angiographical and surgical interventional findings in patients with this anatomical variant.

Key words: angiography, ramus intermedius artery.

$$
\text { الدراسة الوعائية للشريان التاجي المتوسط في البصرة }
$$

الخلفية : الشريان التاجي المتوسط احد فروع شرايين القلب التاجية والذي يغذي الجدار الجانبي للبطين الأيسر ويعتبر تباين تشريحي طبيعي يمثل ثلاثية الفروع للشريان التاجي الأيسر. إن تصلب هذا الشريان يؤدي إلى إعراض سريرية خاصة حتى لو كانت الشرايين التاجية الرئيسية سليمة وعند ذلك نحتاج إلى التداخل القسطاري أو تداخل القلب الجراحي. الهدف: لمعرفة مدى وجود الثريان المتوسط بين سكان البصرة وأهمية حدوثه في تفسير التصوير الوعائي للشرايين التاجية وإعادة الإنعاش الجراحي لعضلة القلب.

طريقة إجراء الدراسة والمرضى: أجريت دراسة استطلاعية لتصوير الشرايين التاجية في مركز قسطرة القلب في مستشفى الصدر التعليمي على المرضى من ذوي شرايين تاجية سليمة.

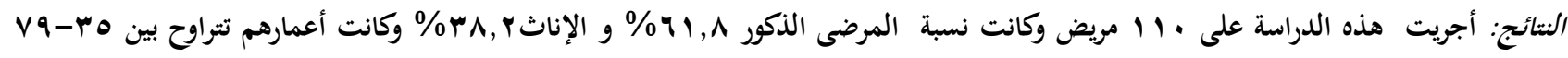

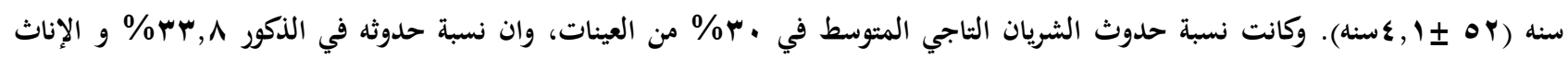

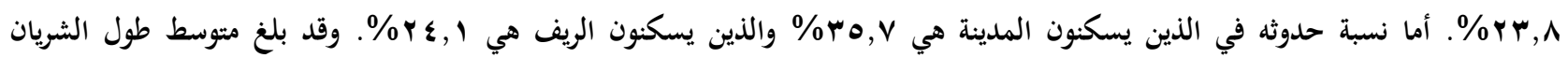

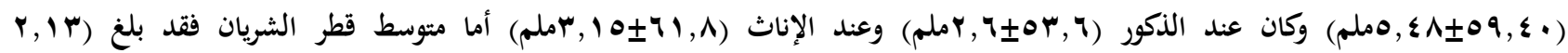

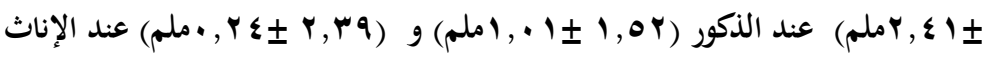
الاستنتاجات: إن الشريان التاجي المتوسط له أهمية كبرى في نتائج التداخل القسطري والجراحي عند المرضى الذين لديهم هذا البديل التشريحي.

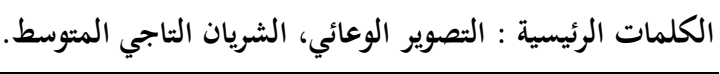




\section{INTRODUCTION}

$\mathrm{T}$ he left main stem is one of main coronary arteries. It either bifurcates into anterior descending artery and left circumflex artery or in some people it trifurcated into anterior descending artery, left circumflex artery and ramus intermedius (median artery or intermediate artery). ${ }^{[1-5]}$ The anterior descending artery supplies the anterolateral wall of left ventricle, apex of heart and superior two thirds of interventricular septum, while left circumflex artery supplies the posterolateral wall of left ventricle and anterolateral papillary muscle. ${ }^{[1,2,4-6]}$ Ramus intermedius is considered as a normal variant; it arises from the angle between the division of the anterior descending artery and the left circumflex artery. It supplies the lateral wall of the left ventricle and it is sometimes so large that it may even reach the apex region. This artery, under conditions of coronary insufficiency, is regarded as an important pattern of the collateral blood flow. ${ }^{[1,2,4,5]}$ The causes of this anatomical changes are either genetic as endothelin-1(ET-1) and endothelin A receptor (ETAR); their signals affect coronary artery development precisely when neural crest cells transform to the coronary artery smooth muscle cells then form the proper coronary artery. ${ }^{[7,8]}$ While the environmental factors has a mitogenic effect. Its mechanism is by acting on the fibroblast growth factor (FGF) and making the cells respond to the effect of mitogens. Both genetic and environmental factors are acting together as the causative factors to this variation. ${ }^{[8-11]}$ There are few advantages of having ramus intermedius artery; firstly it makes left main impedance less because left main blood will empty into three ostia rather than two. The combined cross sectional area of these three ostia confers a hydrodynamic advantage. In addition, any proximal anterior descending artery lesion is negated by $33 \%$ as the two other vessels are there to take care the rest of the heart and lastly the large ramus intermedius artery usually supplies a huge area in the angle between anterior descending artery and left circumflex artery. This is regarded as a potential protection

against ventricular fibrillation during acute occlusion of anterior descending artery by providing electrical stability. The disadvantage of trifurcation is that people with large ramus intermedius artery may have a very small diagonal or obtuse marginal arteries, while the small caliber ramus can often be a disadvantage as it is liable for atherosclerosis since it restricts left main flow by venturi effect. ${ }^{[12]}$

\section{PATIENTS AND METHODS}

This angiographical prospective study was carried out in the cardiac catheterization center at Al Sadder Teaching Hospital ,Basrah governorate during the period extended from January 2013 to the end of August 2013. The sample included patients who lived in Basrah and attended the center during the study period. The patients with history of congenital heart diseases and angiographical findings as ischemic arterial changes were excluded from the study. Both male and female patients were recruited. A structural questionnaire formula was developed and designed for the purpose of the study after being discussed with experts. All cases were interviewed, the interview and data collection was carried out after taken a verbal permission from the patient to participate in this study. The patient should be stable at time of diagnostic angiographical study, each patient had done the following tests: the baseline ECG, electrolyte, renal function tests, complete blood cell count and coagulation tests; that should be reviewed before coronary angiography. Drugs used during coronary angiography: sedation as diazepam 5-10 mg intramuscularly, anticoagulants as heparinized saline is still required during routine coronary arteriography, contrast dye Ominipaque contrast media $350 \mathrm{mg} /$ $1 \mathrm{cc}$ (each vial contains $100 \mathrm{cc}$ given according 
to body weight) and other drugs used according to the patient condition. These drugs included: intravenous fluid, adrenaline, atropine, hydrocortisone. The coronary angiographies were performed by the Judkin technique through femoral approach by using 6 French femoral sheath and diagnostic catheters.

\section{Catheterization Equipments: The} catheterization equipments used in cardiac catheterization center at $\mathrm{Al}$ Sadder Teaching Hospital were:

*Phillips angiographic equipments: which were used in the center since 2008 and manufactured in Holland.

\section{*General Electrical angiographic} equipments: which were used in the center since 2012 and manufactured in USA.

\section{RESULTS}

The sample size was 110 cases; male patients were $68(61.8 \%)$ and the female patients were 42 (38.2\%); the age of patients were ranged from 35 to 79 years $(52 \pm 4.1$ years $)$. This study revealed that the ramus intermedius artery was absent in 77(70\%) and present in 33(30\%) cases of right dominant circulation. The incidence of ramus intermedius artery in male patients was $33.8 \%$ and in females $23.8 \%$ while the incidence of this artery in people who live in urban area was $35.7 \%$, rural area $24.1 \%$. The P values between incidence of ramus intermedius artery and gender and presidency were 0.214 and 0.74 respectively which is statistically insignificant. The length of ramus intermedius artery was variable with a mean of $59.40 \pm$ $5.48 \mathrm{~mm}$ ( in males $53.6 \pm 2.6 \mathrm{~mm}$ and females $61.8 \pm 3.15 \mathrm{~mm})$. The mean caliber of this artery was $2.13 \pm 2.41 \mathrm{~mm}$ (in males $1.52 \pm 1.01 \mathrm{~mm}$ and females $2.39 \pm 0.24 \mathrm{~mm}$ ). The length and caliber of ramus intermedius artery showed no statistically significant difference among male and female patients $(\mathrm{P}=0.25, \mathrm{P}=0.63)$. (Table 1-4 and Figure 1-2).

Table 1. Distribution of cases according to ramus intermedius artery presentation.

\begin{tabular}{||l|c|c||}
\hline \hline Ramus Intermedius Artery & No. of Patients & \% \\
\hline Absent & 77 & 70 \\
\hline Present & 33 & 30 \\
\hline Total & 110 & 100 \\
\hline
\end{tabular}

Table 2. Distribution of ramus intermedius artery according to gender.

\begin{tabular}{|c|c|c|c|c|c|c|c||}
\hline \hline \multirow{2}{*}{ Ramus intermedius artery } & \multicolumn{2}{|c|}{$\begin{array}{c}\text { Male } \\
(\mathbf{n = 6 8})\end{array}$} & \multicolumn{2}{c|}{$\begin{array}{c}\text { Female } \\
(\mathbf{n}=\mathbf{4 2})\end{array}$} & \multicolumn{2}{c|}{$\begin{array}{c}\text { Total } \\
(\mathbf{n = 1 1 0})\end{array}$} & \multirow{2}{*}{ P value } \\
\cline { 2 - 8 } & No. & $\boldsymbol{\%}$ & No. & $\boldsymbol{\%}$ & No. & $\%$ & \\
\hline Absent & 45 & 66.2 & 32 & 76.2 & 77 & 70 & \multirow{2}{*}{$\mathbf{0 . 2 1 4}$} \\
\hline Present & 23 & 33.8 & 10 & 23.8 & 33 & 30 & \\
\hline
\end{tabular}

Table 3. Distribution of ramus intermedius artery according to residency.

\begin{tabular}{||c|c|c|c|c|c|c|c||}
\hline \hline Ramus intermedius artery & \multicolumn{2}{|c|}{$\begin{array}{c}\text { Urban } \\
(\mathrm{n}=56)\end{array}$} & \multicolumn{2}{c|}{$\begin{array}{c}\text { Rural } \\
(\mathrm{n}=54)\end{array}$} & \multicolumn{2}{c||}{$\begin{array}{c}\text { Total (n =110 ) } \\
\text { value }\end{array}$} \\
\hline & No. & $\%$ & No. & $\%$ & No. & $\%$ & \\
\hline Absence & 36 & 64.3 & 41 & 75.9 & 77 & 70 & \multirow{2}{*}{0.74} \\
\hline Present & 20 & 35.7 & 13 & 24.1 & 33 & 30 & \\
\hline
\end{tabular}


Table 4. The ramus intermedius artery measurements.

\begin{tabular}{||c|c|c|c|c|c|c||}
\hline \multirow{3}{*}{ Variables } & \multicolumn{2}{|c|}{ Male } & \multicolumn{2}{c|}{ Female } & \multicolumn{2}{c||}{ Total } \\
\cline { 2 - 7 } & $\begin{array}{c}\text { Mean } \\
(\mathbf{m m})\end{array}$ & $\begin{array}{c}\text { Std. } \\
\text { Deviation }\end{array}$ & $\begin{array}{c}\text { Mean } \\
(\boldsymbol{m m})\end{array}$ & Std. Deviation & $\begin{array}{c}\text { Mean } \\
(\boldsymbol{m m})\end{array}$ & Std. Deviation \\
\hline Length & 53.6 & 2.6 & 61.8 & 3.15 & 59.40 & 5.48 \\
\hline Caliber & 1.52 & 1.01 & 2.39 & 0.24 & 2.13 & 2.41 \\
\hline \hline
\end{tabular}

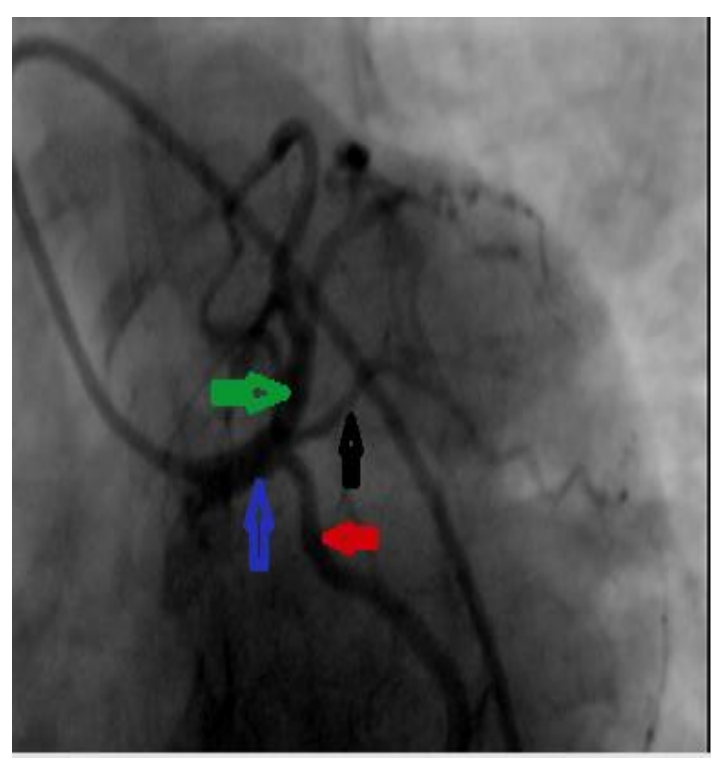

a

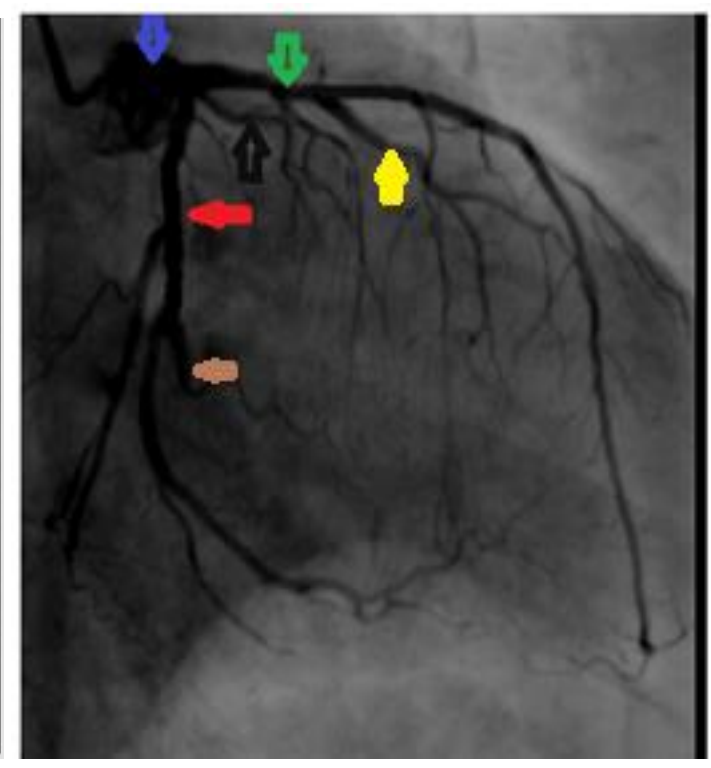

b

Fig 1. Coronary angiogram in LAO, RAO projections showing left coronary artery (blue arrow) trifurcated to 3 branches: anterior descending artery (green arrow), left circumflex artery (red arrow) and short median artery (black arrow).

Note: short median artery but large diagonal artery (yellow arrow) and large obtuse marginal artery (brown arrow)
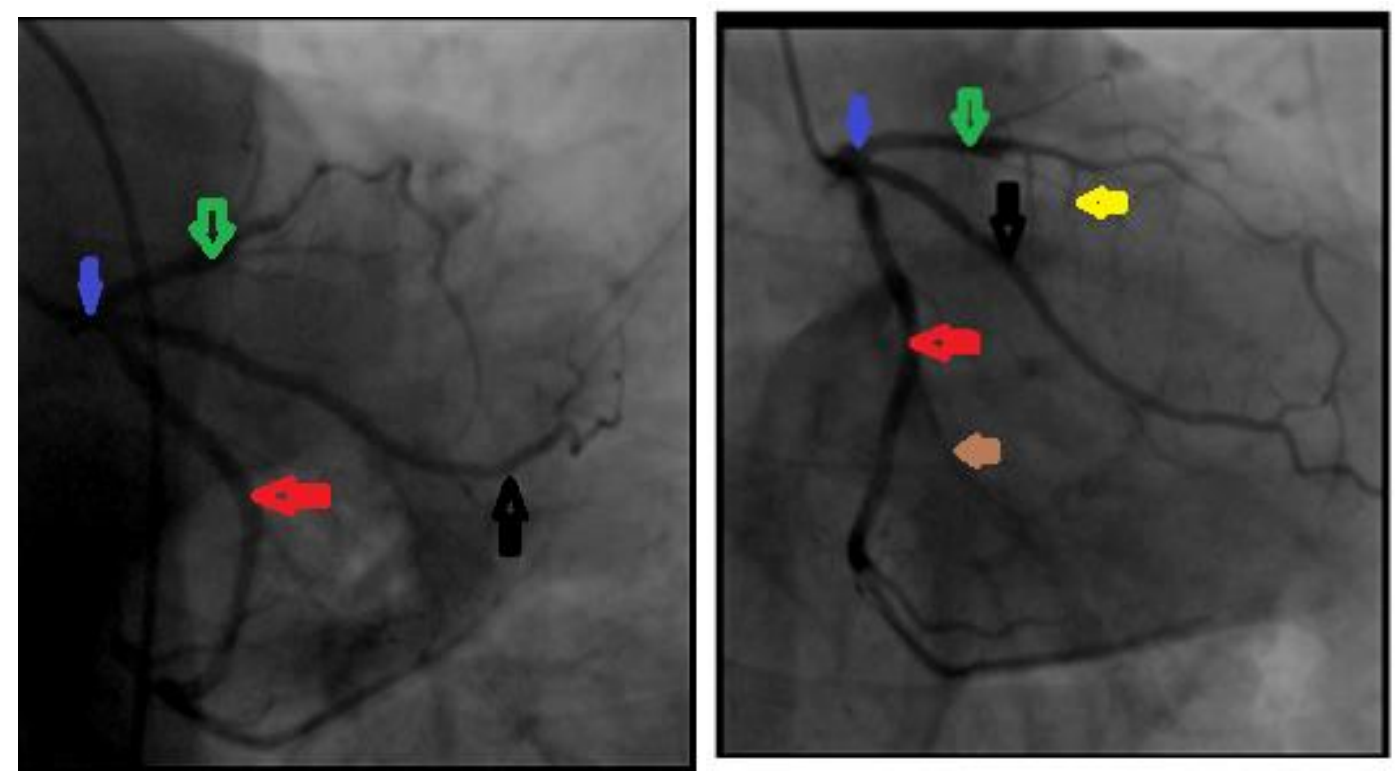

Fig 2. Coronary angiogram in RAO projection showing left coronary artery (blue arrow) trifurcated to 3 branches: anterior descending artery (green arrow), left circumflex artery (red arrow) and long median artery (black arrow) reached to heart apex.

Note: long median artery but small diagonal artery (yellow arrow) and small obtuse marginal artery (brown arrow) 


\section{DISCUSSION}

In our study the ramus intermedius artery was present in $30 \%$ of cases. This is in agreement with Bhimalli et al., Cadmartiri et al.; Fazliogullari et al., and Kalpana ${ }^{[13-16]}$ but it disagreed with Mehta et al. ${ }^{[17]}$ This variations may be due to geographical and genetic differences ${ }^{[10]}$ In the present study, the mean length of ramus intermedius artery $(59.40 \pm 5.48$ $\mathrm{mm}$ ) in male $53.6 \pm 2.6 \mathrm{~mm}$, female $61.8 \pm 3.15$ $\mathrm{mm}$ on the other hand the caliber of this artery $(2.13 \pm 2.41 \mathrm{~mm})$ in male was $1.52 \pm 1.01 \mathrm{~mm}$, female $2.39 \pm 0.24 \mathrm{~mm}$ but no similar studies related to ramus intermedius artery measurements could be found. The size of ramus intermedius varies greatly from a very small vessel to a very large branching vessel which may displace the need for significant anterior descending diagonals or left circumflex marginal's . ${ }^{[18]}$ Ortale et al. and Kosar et al. ${ }^{[3,18]}$ reported that the obtuse marginal arteries, diagonal arteries and ramus artery have a complementary role to each other, and when one is absent or small in caliber the others contributed to its territory. Cadmartiri et al. ${ }^{[13]}$ was observed a similar relation between diagonal arteries and ramus intermedius. The presence of ramus intermedius artery has a clinical consequences especially in catheterization that will cause technical difficulties and may be a source of misdiagnosis or complications. ${ }^{[18,19]}$ Because ramus intermedius artery is an early branch from left main stem, it might have a predilection for atherosclerosis similar to anterior descending artery or left circumflex artery. When ramus is involved in acute coronary syndrome, the patient could present with ST elevation in lead 1, AVL,V5,V6 as in lateral myocardial infarction and / or apical myocardial infarction. Under this condition, if ramus is involved, adjacent anterior descending artery and left circumflex artery are also likely to be involved in percutanous coronary intervention with a multivessel complex angioplasty; however isolated ramus lesion could be easily tackled. ${ }^{[12]}$ In addition ramus is not lying within any anatomical groove so stenting procedure will have a poor support and liable for mobilization and migration. ${ }^{[12]}$

\section{REFERENCES}

1. Snell RS. Clinical Anatomy, 7th edition. Lippincott Williams \& Wilkins: Wolters Kluwer. 2004; 105-117.

2. Drake RL, Vogl W, Mitchell AW. Gray's Anatomy for Students. London: Churchill Livingstone. 2004; 3:154-181.

3. Ortale JR, Meciano FJ, Paccola AF, Leal JG, Sacaranari CA. Anatomy of the lateral, diagonal and anterosuperior arterial branches of the left ventricle of the human heart. Braz J Cardiovasc Surg. 2005; 20: 149-158.

4. Kini S, Kostaki GB, Weaver L. Normal and Variant Coronary Arterial and Venous Anatomy on High - Resolution CT Angiography. AJR 2007; 188: 1665-1674.

5. Telkar BH. Multi-detector coronary angiography. Radiology 2002; 223: 212-220.

6. Bastarrika AG, Alonso BA, Azcarate APM, Castaño RS, Pueyo VJC, Alegría EE. Normal anatomy, anatomical variants and anomalies of the origin and course of the coronary arteries on multislice CT. Radiologia 2008 ; 50(3): 197-206.

7. Arima Y, Miyagawa ST, Maeda K, Asai R, Seya $\mathrm{D}$, Minoux M, et al. The Novel Contribution of Preotic Neural Crest Cells in the Coronary Artery Development. Circulation 2012; 126: A14270.

8. Arima $Y$, Miyagawa ST, Nishiyama $K$, Asai R, Kim KS, Uchijima $\mathrm{Y}$, et al. Coronary Artery Anomalies in Endothelin-1 and Endothelin A Receptor Knockout Mice. Circulation 2011; 124: A11552.

9. Schwartz SM., Liaw L. Growth Control and Morphogenesis in the Development and Pathology of Arteries. Journal of Cardiovascular Pharmacology 1993; 21 (1): 31-49.

10. Olabu B, Saidi HS, Hassanali J, Ogeng'o JA. Prevalence and Distribution of The Third Coronary Artery In Kenyans. International Journal of Morphology 2007; 25(4): 851-854.

11. Garg N, Tewari S, Kapoor A, Gupta DK, Sinha N. Primary congenital anomalies of the 
coronary arteries: A coronary Arteriographic study. Int. J. Cardio 2000; 74(7): 39-46.

12. Venkatesan S. Expression in cardiology. 2008 available at

https://drsvenkatesan.wordpress.com /2008/12/16/what-is-clinical-significance-oframus-intermedius-coronary-artery

13. Cademartiri F, La Grutta L, Malagò R, Alberghina F, Meijboom WB, Pugliese F, et al. Prevalence of anatomical variants and coronary anomalies in 543 consecutive patients studied with 64-slice CT coronary angiography. Eur Radiol. 2008; 18: 781-791.

14. Fazliogullari Z, Karabulut AK, Unver ND, Uysal I. Coronary artery variations and median artery in Turkish cadaver hearts. Singapore Med J 2010; 51(10): 775.

15. Bhimalli S, Dixit D, Siddibhavi M, Shirol VS. A study of variations in coronary arterial system in cadaveric human heart. World Journal of Science and Technology 2011; 1(5): 30-35.
16. Kalpana R. A Study on principal branches of coronary artery in humans. J. Anat. Soc. 2003; 52(2): 137- 140.

17. Mehta R, Agarwal S. Evaluation of anatomic variations in coronary artery on 64-sliced computed tomography CTA. Int J Cur Res Rev (IJCRR)2013: 5(15): 23-30.

18. Koşar P, Ergun E, Öztürk C, Koşar U. Anatomic variations and anomalies of the coronary arteries: 64-slice angiographic appearance. Journal of the Turkish Society of Radiology 2009; 15(4): 275-283.

19. Tomar S, Aga P, Sharma PK, Manik P, Srivastava AK. Normal and variant anatomy of Left Coronary Artery: 64-Slice Multi Detector Computed Tomography (MDCT) Coronary Angiographic Depiction in North Indian population. International Journal of Scientific and Research Publications 2013; Vol. 3 (8):1-17. 